\title{
Evaluation of sweet cherry fruit quality after short-term storage in relation to the rootstock
}

\author{
Ewa Dziedzic $^{1}$ [D Jan Błaszczyk ${ }^{1}$
}

Received: 8 January 2018 / Revised: 6 September 2019 / Accepted: 24 September 2019 / Published online: 28 October 2019

(c) The Author(s) 2019

\begin{abstract}
Fruits of the sweet cherry cultivar 'Regina' collected from trees growing on seven rootstocks were stored in a cold room at $2{ }^{\circ} \mathrm{C}$ with a normal (NA) and controlled atmosphere (15\% and $20 \% \mathrm{CO}_{2}$ and $5 \% \mathrm{O}_{2}-\mathrm{CA} 1$ and CA2) for 2 weeks. The rootstocks on which the trees grew and the storage conditions significantly affected all fruit parameters tested during both years of the experiment. Fruit from Damil rootstock exhibited higher mean firmness than fruit from Colt rootstock. The effect of rootstocks on the value of soluble solids content (SSC) varied, wherein the fruits from Tabel Edabriz and Damil were characterized by high SSC mean content. The organic acids content (TA) was significantly lower after storage than during harvest time. Fruits from Tabel Edabriz trees were characterized by faster ripening, as was evident by the higher SSC to TA ratio. The amount of mass lost depended significantly and only on the storage conditions-sweet cherries from both CA combinations had the lowest mass losses. The percentage of fruits showing disease symptoms was largely dependent on the weather conditions in the orchard the year before the fruit harvest, as well as atmosphere composition and RH during fruit storage. Cold storage conditions with a high (20\%) $\mathrm{CO}_{2}$ content are recommended for the short-term storage of sweet cherry fruits because they preserve fruit quality parameters: a low decrease in firmness, maintenance of a high SSC/TA ratio, a low percent of fungal infections, and good preservation of green color in the peduncle.
\end{abstract}

Keywords Controlled atmosphere $\cdot$ Firmness $\cdot$ Maintenance of green peduncle $\cdot$ Soluble solids content $\cdot$ Titratable acidity

\section{Introduction}

The world currently produces about 2.3 million tons of cherries. Most of these fruits come from Asia (43\%), Europe (37\%) and America (18\%). The top ten producing countries supply more than $70 \%$ of cherries to the markets. Turkey $(535,000 \mathrm{t})$, the USA $(345,000 \mathrm{t})$ and China $(220,000 \mathrm{t})$ are the largest producers. Polish production (according to USDA estimates) is about 50,000 t. Sweet cherry is a perishable fruit, characterized by a high water content in tissues, thin skin and high respiration intensity (Wang and Lang 2014). Harvest of non-climatic fruits (sweet cherries) usually occurs after full maturity, at the stage of consumption

Communicated by Jeong Hee Choi.

Ewa Dziedzic

e.dziedzic@urk.edu.pl

1 Department of Pomology and Apiculture, University of Agriculture in Krakow, 29-Listopada 54, 32-425 Kraków, Poland maturity, similarly to plum (Candan et al. 2011) and contrary to apple (Hărsan et al. 2006). Sweet cherry fruits are highly appreciated by consumers due to their excellent taste and high nutritional values, and they are consumed mainly as a dessert fresh fruit (Crisosto et al. 2003). Therefore, short cool storage technology is often applied to extend the fresh fruit supply to the market. However, sweet cherry fruits can be stored for a relatively short time (up to 8 weeks) under optimal storage conditions. Lately, studies concerning new storage technologies (modified atmosphere packaging, air and water precooling) have been conducted (Remón et al. 2000; Akbulut and Özcan 2008; Khorshidi et al. 2011; Giacalone and Chiabrando 2013). The rootstock used for growing fruit trees affects many traits of trees and fruits, such as tree vigor (Balmer 2008), flower bud induction and regular bearing (Koutinas et al. 2010), productivity index (Bielicki and Rozpara 2010), fruit mass (Gratacós et al. 2008), or cracking susceptibility (Brüggenwirth and Knoche 2016). Moreover, it also has an impact on such fruit characteristics as: size, firmness, soluble solids content, acidity, color (fruit, peduncle) and taste (Simon et al. 2004; Gratacós et al. 2008; 
Kankaya et al. 2008); rootstock can affect both harvest and postharvest periods. Trees of different vigor can produce sweet cherry fruits with different phenolic acid and flavonol contents. Sometimes, vitamin, polyphenol and anthocyanin contents in fruit can also be affected by the rootstock (Spinardi et al. 2005). Wild growing sweet cherry genotypes have different nutritional properties than light skin colored ones (Karlidag et al. 2009). The most often conducted experiments on the effect of rootstocks concern the evaluation of fruit quality characteristics during tree growth and development until fruit harvest (Kurlus 2008). However, the most frequent studies concern the effect of the rootstock on fruit quality characteristics during growth and development up to the time of harvest, while assessments of the effect of rootstock type on the properties of sweet cherry fruits during and after cool storage are rare and fragmented (Cavalheiro et al. 2005; Dziedzic et al. 2016, 2017). Therefore, we aimed to evaluate how the short-term storage of sweet cherry fruits relates to the effect of rootstocks, on which sweet cherry trees are cultivated in orchards. Over 2 years, we studied the effect of seven rootstocks (vigorous and dwarf) and two controlled atmosphere conditions (with high $\mathrm{CO}_{2}$ concentration) on the quality of 'Regina' sweet cherry fruits after two-week cold storage. We also compared the present results with our earlier observations of the cultivar 'Regina' after storage in less favorable conditions.

\section{Materials and methods}

Trees of the sweet cherry (Prunus avium L) cultivar 'Regina' (late-season, large, dark red, firm, very resistant to rain cracking) were cultivated in the Experimental Station located near Krakow, $270 \mathrm{~m}$ above the sea level $\left(50^{\circ} 09^{\prime} \mathrm{N}, 19^{\circ} 56^{\prime} \mathrm{E}\right)$. Trees were planted on seven rootstocks (Colt, Damil, Gisela 5, Mazzard F12.1, P - HL A, Tabel Edabriz and Weiroot 10) in 2003, in $5 \times 2.5 \mathrm{~m}$ spacing. Weed control was maintained with herbicides in tree rows and with grass between rows. Flowers in the orchard were pollinated using pollen from the sweet cherry $\mathrm{cv}$. 'Kordia'. Chemical protection of trees was carried out according to the recommendation for commercial orchards. Fruits were harvested on July 7th, 2014 and July 10th, 2015 during commercial maturity (stage). In 2015, there was no crop of sweet cherry fruits on trees growing on the 'Mazzard F12.1' rootstock. Immediately after harvest, fruits were transported to the laboratory (Department of Pomology and Apiculture) and subjected to a first assessment for firmness, soluble solids contents (SSC) and titratable acidity (TA). Random fruit samples $(4$ (replicates) $\times 500 \mathrm{~g}$ ) from five trees from each rootstock combination were evaluated. Firmness was determining using a TA 500 Texture Analyzer (Lloyd Instruments Ltd., UK) equipped with an 8-mm tip and values were expressed in Newtons (N). Fruit SSC was determined by a digital refractometer
(PR-101, Atago, Tokyo, Japan) at $20^{\circ} \mathrm{C}$ and expressed as a percentage. Titratable acidity (TA) was determined by potentiometric titration to $\mathrm{pH} 8.1$ with $0.1 \mathrm{~N} \mathrm{NaOH}$, up to $\mathrm{pH} 8.1$ using $5 \mathrm{ml}$ of diluted juice in $100 \mathrm{ml}$ distilled $\mathrm{H}_{2} \mathrm{O}$, and the results were expressed as the percentage of malic acid. The color in the fruit peduncle was estimated visually, according to Royal Horticultural Society's Color Chart (RHS, UK). Fruit samples (replicates, $500 \mathrm{~g}$ each) from each treatment (3 storage combination $\times 7$ rootstocks in 2014 and 3 storage combination $\times 6$ rootstocks in 2015) were stored in plastic containers for 2 weeks, in three storage conditions: controlled atmosphere 1 (CA1) $\left(15 \% \mathrm{CO}_{2}\right.$ and $3 \% \mathrm{O}_{2}$, RH $\left.90-92 \%, 2{ }^{\circ} \mathrm{C}\left( \pm 0.5{ }^{\circ} \mathrm{C}\right)\right)$, controlled atmosphere 2 (CA2) $\left(20 \% \mathrm{CO}_{2}\right.$ and $3 \% \mathrm{O}_{2}$, $\mathrm{RH}$ $90-92 \%, 2{ }^{\circ} \mathrm{C}\left( \pm 0.5^{\circ} \mathrm{C}\right)$ ), and normal atmosphere (NA) (RH $80 \%, 2^{\circ} \mathrm{C}$ ). After storage, the following fruit parameters were investigated: fruit firmness, SSC, TA and the SSC/TA ratio. The loss of fruit mass was recorded as a percentage by weighing fruit in each condition before and after the storage period. Moreover, maintenance of fungal decay and green color in the fruit peduncle was visually assessed and expressed as percentages. The greenness of the peduncle was assessed visually according to the Royal Horticultural Society's Color Chart (RHS, UK) as a percentage.

The average temperature and total precipitation were measured in May, June and July; during these months the average temperature was $13.6{ }^{\circ} \mathrm{C}, 13.8^{\circ} \mathrm{C}$ and $20.2{ }^{\circ} \mathrm{C}$, respectively, in 2014 and $12.9{ }^{\circ} \mathrm{C} 16.9{ }^{\circ} \mathrm{C}$ and $19.4{ }^{\circ} \mathrm{C}$, respectively, in 2015. Total atmospheric precipitation was also recorded in May and June, and in July only until fruit harvest, and it amounted to $142.2 \mathrm{~mm}, 134.1 \mathrm{~mm}$ and $4.5 \mathrm{~mm}$ in 2014 and $141.4 \mathrm{~mm}, 92.7 \mathrm{~mm}$ and $35.6 \mathrm{~mm}$ in 2015 , respectively.

\subsection{Statistical analysis}

The experiment was conducted over two seasons, with four replications for each combination. The data were analyzed using two-way analysis of variance (ANOVA) and Statistica software (StatSoft Inc., v.12, USA); calculations were conducted for each season separately. The values expressed as percentage were transformed according to the Bliss function $(y=\operatorname{arc} \sin \sqrt{ } x)$. Tukey's HSD test was used to determine the significance of differences between mean values at the significance level of $p \leq 0.05$.

\section{Results}

\subsection{Fruit quality at harvest}

The analyses carried out after fruit harvest showed that the type of rootstock on which sweet cherry trees of the cultivar 'Regina' grew had a significant impact on all analyzed 
fruit quality parameters, except for fruit firmness, in both years of the experiment. Generally, the fruits had lower firmness in the first year $(14.6 \mathrm{~N})$ compared to the second year $(18.4 \mathrm{~N})$ of the experiment (Table 1). Each year, SSC and TA varied depending on the rootstock. The fruit from the Damil rootstock exhibited high SSC values in both the first and second year (16.0\% and $18.7 \%$, respectively) (Table 2). Fruit from the P- HL A rootstock exhibited higher titratable acidity (TA) in the first and the second year $(0.69 \mathrm{mg}$ $100 \mathrm{~g}^{-1}$ and $0.91 \mathrm{mg} 100 \mathrm{~g}^{-1}$, respectively), compared to fruits from the Damil $\left(0.62 \cdot 100 \mathrm{~g}^{-1}\right.$ and $0.79 \mathrm{mg} 100 \mathrm{~g}^{-1}$, respectively) and Tabel-Edabriz rootstocks $\left(0.60 \mathrm{mg} 100 \mathrm{~g}^{-1}\right.$ and $0.68 \mathrm{mg} 100 \mathrm{~g}^{-1}$, respectively) (Table 3). During both years, fruit from the Tabel-Edabriz rootstock had a high SSC to TA ratio (Table 4).

After 2 weeks of fruit storage, the studied factors-i.e., storage conditions and rootstocks on which 'Regina' sweet cherries trees grew-and the interaction between these factors significantly influenced the majority of the assessed fruit parameters.

Table 1 Fruit firmness (N) of 'Regina' sweet cherries directly after harvest and storage as affected by rootstocks and storage conditions

\begin{tabular}{|c|c|c|c|c|c|c|}
\hline \multirow[t]{2}{*}{ Year } & \multirow[t]{2}{*}{$\begin{array}{l}\text { Rootstock } \\
\text { (A) }\end{array}$} & \multirow[t]{2}{*}{ Harvest } & \multicolumn{3}{|c|}{$\begin{array}{l}\text { Storage conditions } \\
\text { (B) }\end{array}$} & \multirow[t]{2}{*}{ Rootstock means } \\
\hline & & & NA & CA 1 & CA 2 & \\
\hline 2014 & $\begin{array}{l}\text { Colt } \\
\text { Damil } \\
\text { Gisela 5 } \\
\text { Mazzard F } 12.1 \\
\text { P-HLA } \\
\text { Tabel-Edabriz } \\
\text { Weiroot } 10\end{array}$ & $\begin{array}{l}12.9 \pm 2.94 * \\
15.9 \pm 4.43 \\
13.9 \pm 2.42 \\
13.2 \pm 3.66 \\
14.6 \pm 3.38 \\
14.7 \pm 3.60 \\
17.4 \pm 5.25\end{array}$ & $\begin{array}{l}10.3 \pm 2.42 \\
10.8 \pm 2.03 \\
11.3 \pm 2.48 \\
9.1 \pm 2.42 \\
11.2 \pm 2.49 \\
11.8 \pm 2.15 \\
10.6 \pm 2.47\end{array}$ & $\begin{array}{l}12.4 \pm 2.48 \\
13.8 \pm 4.39 \\
13.8 \pm 2.08 \\
12.0 \pm 3.73 \\
14.3 \pm 2.55 \\
13.3 \pm 2.86 \\
14.7 \pm 4.44\end{array}$ & $\begin{array}{l}12.8 \pm 1.88 \\
14.1 \pm 3.05 \\
13.8 \pm 3.55 \\
13.1 \pm 3.49 \\
14.5 \pm 2.68 \\
14.2 \pm 2.74 \\
15.0 \pm 4.51\end{array}$ & $\begin{array}{l}12.1 \pm 1.05 \\
13.7 \pm 1.83 \\
13.2 \pm 1.10 \\
11.9 \pm 1.66 \\
13.7 \pm 1.42 \\
13.5 \pm 1.11 \\
14.4 \pm 2.44\end{array}$ \\
\hline Harvest/storage means & & $14.6 \pm 1,46 \mathrm{~b}$ & $10.7 \pm 0.82 \mathrm{a}$ & $13.5 \pm 0.91 \mathrm{~b}$ & $13.9 \pm 0.71 \mathrm{~b}$ & Rootstock means \\
\hline 2015 & $\begin{array}{l}\text { Colt } \\
\text { Damil } \\
\text { Gisela 5 } \\
\text { P-HL A } \\
\text { Tabel-Edabriz } \\
\text { Weiroot } 10\end{array}$ & $\begin{array}{l}18.1 \pm 2.98 \\
18.5 \pm 2.62 \\
19.1 \pm 2.65 \\
17.5 \pm 3.18 \\
19.8 \pm 4.51 \\
17.3 \pm 3.11\end{array}$ & $\begin{array}{l}14.5 \pm 2.57 \\
17.4 \pm 3.17 \\
17.4 \pm 2.97 \\
14.9 \pm 2.07 \\
15.5 \pm 2.52 \\
13.7 \pm 4.58\end{array}$ & $\begin{array}{l}17.4 \pm 3.55 \\
18.1 \pm 3.54 \\
18.7 \pm 2.71 \\
17.0 \pm 2.01 \\
16.2 \pm 3.04 \\
14.1 \pm 3.96\end{array}$ & $\begin{array}{l}17.0 \pm 2.69 \\
18.1 \pm 3.50 \\
17.6 \pm 3.17 \\
17.0 \pm 2.78 \\
16.3 \pm 3.90 \\
16.3 \pm 4.05\end{array}$ & $\begin{array}{l}16.7 \pm 1.36 \\
18.0 \pm 0.40 \\
18.2 \pm 0.72 \\
16.6 \pm 1.00 \\
16.9 \pm 1.67 \\
15.3 \pm 1.50\end{array}$ \\
\hline Harvest/storage means & & $18.4 \pm 0.87 \mathrm{~b}$ & $15.6 \pm 1.40 \mathrm{a}$ & $16.9 \pm 1.49 \mathrm{ab}$ & $17.1 \pm 0.65 \mathrm{ab}$ & \\
\hline
\end{tabular}

*Means followed by the same small letter within a row and capital letter within a column, for each year, do not differ significantly at $\alpha=0.05$ $N A$ normal atmosphere, $C A 1$ control atmosphere $15 \% \mathrm{CO}_{2}+3 \% \mathrm{O}_{2}, C A 2$ control atmosphere $20 \% \mathrm{CO}_{2}+3 \% \mathrm{O}_{2}$

Table 2 Soluble solids content (\%) of 'Regina' sweet cherry directly after harvest and storage as affected by rootstock and storage conditions

\begin{tabular}{|c|c|c|c|c|c|c|}
\hline \multirow[t]{2}{*}{ Year } & \multirow[t]{2}{*}{$\begin{array}{l}\text { Rootstock } \\
\text { (A) }\end{array}$} & \multirow[t]{2}{*}{ Harvest } & \multicolumn{3}{|c|}{$\begin{array}{l}\text { Storage conditions } \\
\text { (B) }\end{array}$} & \multirow[t]{2}{*}{ Rootstock means } \\
\hline & & & NA & CA 1 & CA 2 & \\
\hline 2014 & $\begin{array}{l}\text { Colt } \\
\text { Damil } \\
\text { Gisela } 5 \\
\text { Mazzard F } 12.1 \\
\text { P-HL A } \\
\text { Tabel-Edabriz } \\
\text { Weiroot } 10\end{array}$ & $\begin{array}{l}15.7 \pm 0.24 \mathrm{aCD} * \\
16.0 \pm 0.63 \mathrm{aD} \\
16.3 \pm 0.24 \mathrm{aD} \\
11.4 \pm 0.16 \mathrm{aA} \\
15.0 \pm 0.65 \mathrm{aC} \\
16.0 \pm 0.41 \mathrm{aD} \\
13.9 \pm 0.65 \mathrm{aB}\end{array}$ & $\begin{array}{l}15.9 \pm 0.49 \mathrm{aC} \\
16.1 \pm 0.25 \mathrm{aC} \\
16.1 \pm 0.62 \mathrm{aC} \\
11.9 \pm 0.19 \mathrm{aA} \\
15.0 \pm 0.29 \mathrm{aB} \\
17.2 \pm 0.10 \mathrm{bD} \\
15.6 \pm 0.52 \mathrm{cBC}\end{array}$ & $\begin{array}{l}15.5 \pm 0.34 \mathrm{aBC} \\
16.5 \pm 0.31 \mathrm{aD} \\
16.2 \pm 0.31 \mathrm{aCD} \\
11.2 \pm 0.19 \mathrm{aA} \\
15.5 \pm 0.28 \mathrm{aBC} \\
16.9 \pm 0.12 \mathrm{bD} \\
15.0 \pm 0.36 \mathrm{bcB}\end{array}$ & $\begin{array}{l}15.7 \pm 0.52 \mathrm{aC} \\
16.6 \pm 0.39 \mathrm{aD} \\
15.6 \pm 0.40 \mathrm{aC} \\
11.5 \pm 0.05 \mathrm{aA} \\
15.0 \pm 0.16 \mathrm{aC} \\
16.7 \pm 0.42 \mathrm{abD} \\
14.2 \pm 0.16 \mathrm{abB}\end{array}$ & $\begin{array}{l}15.7 \pm 0.14 \mathrm{c} \\
16.3 \pm 0.25 \mathrm{de} \\
16.1 \pm 0.27 \mathrm{~cd} \\
11.5 \pm 0.25 \mathrm{a} \\
15.1 \pm 0.22 \mathrm{~b} \\
16.7 \pm 0.44 \mathrm{e} \\
14.7 \pm 0.67 \mathrm{~b}\end{array}$ \\
\hline Harvest/storage means & & $14.9 \pm 1.71 \mathrm{a}$ & $15.4 \pm 1.61 \mathrm{c}$ & $15.3 \pm 1.80 \mathrm{bc}$ & $15.0 \pm 1.71 \mathrm{ab}$ & Rootstock means \\
\hline 2015 & $\begin{array}{l}\text { Colt } \\
\text { Damil } \\
\text { Gisela } 5 \\
\text { P-HL A } \\
\text { Tabel-Edabriz } \\
\text { Weiroot } 10\end{array}$ & $\begin{array}{l}16.5 \pm 0.41 \mathrm{aBC} \\
18.7 \pm 0.24 \mathrm{bD} \\
17.1 \pm 0.73 \mathrm{aC} \\
15.8 \pm 0.49 \mathrm{abA} \\
22.4 \pm 0.62 \mathrm{abE} \\
16.1 \pm 0.16 \mathrm{aAB}\end{array}$ & $\begin{array}{l}17.6 \pm 0.40 \mathrm{bB} \\
18.4 \pm 0.17 \mathrm{abC} \\
16.6 \pm 0.26 \mathrm{aA} \\
16.3 \pm 0.34 \mathrm{bA} \\
22.7 \pm 0.12 \mathrm{abD} \\
15.9 \pm 0.09 \mathrm{aA}\end{array}$ & $\begin{array}{l}17.6 \pm 0.16 \mathrm{bC} \\
17.9 \pm 0.36 \mathrm{aC} \\
16.9 \pm 0.54 \mathrm{aB} \\
15.7 \pm 0.08 \mathrm{abA} \\
22.0 \pm 0.16 \mathrm{aD} \\
16.2 \pm 0.68 \mathrm{aA}\end{array}$ & $\begin{array}{l}17.1 \pm 0.24 \mathrm{aC} \\
18.3 \pm 0.33 \mathrm{abD} \\
16.6 \pm 0.28 \mathrm{aBC} \\
15.4 \pm 0.10 \mathrm{aA} \\
22.9 \pm 0.22 \mathrm{bE} \\
16.0 \pm 0.14 \mathrm{aAB}\end{array}$ & $\begin{array}{l}17.2 \pm 0.45 \mathrm{c} \\
18.3 \pm 0.29 \mathrm{~d} \\
16.8 \pm 0.21 \mathrm{~b} \\
15.8 \pm 0.32 \mathrm{a} \\
22.5 \pm 0.34 \mathrm{e} \\
16.0 \pm 0.11 \mathrm{a}\end{array}$ \\
\hline Harvest/storage means & & $17.8 \pm 2.27 \mathrm{a}$ & $17.9 \pm 4.10 \mathrm{a}$ & $17.7 \pm 3.49 \mathrm{a}$ & $17.7 \pm 3.82 \mathrm{a}$ & \\
\hline
\end{tabular}

*Means followed by the same small letter within a row and capital letter within a column, for each year, do not differ significantly at $\alpha=0.05$ 


\subsection{Fruit quality after two-weeks of storage}

\subsubsection{Firmness}

In both years the firmness of the sweet cherry fruit was lower after storage in the NA condition than at harvest time (Table 1). The controlled atmosphere (CA) conditions preserved the firmness of stored fruit at the same level as at harvest time. There was no difference in fruit firmness between two different atmosphere compositions-CA1 and CA2. The effect of rootstock type on the firmness value was not noted.
Also, no significant interaction was found between studied experimental factors (rootstock and storage condition) and fruit firmness.

\subsubsection{Soluble solids content (SSC)}

The studied factors had a significant effect on SSC in fruits for both years, except for the storage condition in the second year (Table 2). In the first year, the increase of SSC in fruits from the NA and CA1 storage conditions in relation to the values measured at harvest time was noted. The effect

Table 3 Titratable Acidity (mg $100 \mathrm{~g}^{-1}$ ) of 'Regina' Sweet Cherry Directly after Harvest and Storage as Affected by Rootstock and Storage Conditions

\begin{tabular}{|c|c|c|c|c|c|c|}
\hline \multirow[t]{2}{*}{ Year } & \multirow{2}{*}{$\begin{array}{l}\text { Rootstock } \\
\text { (A) }\end{array}$} & \multirow[t]{2}{*}{ Harvest } & \multicolumn{3}{|c|}{ Storage conditions (B) } & \multirow[t]{2}{*}{ Rootstock means } \\
\hline & & & NA & CA 1 & CA 2 & \\
\hline 2014 & $\begin{array}{l}\text { Colt } \\
\text { Damil } \\
\text { Gisela } 5 \\
\text { Mazzard F } 12.1 \\
\text { P-HL A } \\
\text { Tabel-Edabriz } \\
\text { Weiroot } 10\end{array}$ & $\begin{array}{l}0.63 \pm 0.02 \mathrm{bAB} * \\
0.62 \pm 0.02 \mathrm{cAB} \\
0.64 \pm 0.03 \mathrm{bBC} \\
0.67 \pm 0.03 \mathrm{bCD} \\
0.69 \pm 0.02 \mathrm{cD} \\
0.60 \pm 0.01 \mathrm{cA} \\
0.65 \pm 0.03 \mathrm{cBC}\end{array}$ & $\begin{array}{l}0.51 \pm 0.02 \mathrm{aC} \\
0.47 \pm 0.02 \mathrm{aAB} \\
0.48 \pm 0.03 \mathrm{aBC} \\
0.51 \pm 0.02 \mathrm{aC} \\
0.50 \pm 0.04 \mathrm{aBC} \\
0.44 \pm 0.02 \mathrm{aA} \\
0.48 \pm 0.01 \mathrm{aBC}\end{array}$ & $\begin{array}{l}0.54 \pm 0.01 \mathrm{aBC} \\
0.54 \pm 0.00 \mathrm{bBC} \\
0.51 \pm 0.00 \mathrm{abAB} \\
0.54 \pm 0.02 \mathrm{aBC} \\
0.56 \pm 0.01 \mathrm{bC} \\
0.48 \pm 0.01 \mathrm{abA} \\
0.53 \pm 0.01 \mathrm{bBC}\end{array}$ & $\begin{array}{l}0.54 \pm 0.01 \mathrm{aB} \\
0.53 \pm 0.01 \mathrm{bAB} \\
0.50 \pm 0.01 \mathrm{abA} \\
0.55 \pm 0.01 \mathrm{aB} \\
0.55 \pm 0.01 \mathrm{bB} \\
0.51 \pm 0.00 \mathrm{bA} \\
0.53 \pm 0.01 \mathrm{bAB}\end{array}$ & $\begin{array}{l}0.55 \pm 0.05 \mathrm{c} \\
0.54 \pm 0.05 \mathrm{bc} \\
0.53 \pm 0.06 \mathrm{~b} \\
0.57 \pm 0.06 \mathrm{~d} \\
0.57 \pm 0.07 \mathrm{~d} \\
0.51 \pm 0.06 \mathrm{a} \\
0.55 \pm 0.06 \mathrm{c}\end{array}$ \\
\hline Harvest/Storage means & & $0.64 \pm 0.03 \mathrm{c}$ & $0.49 \pm 0.03 \mathrm{a}$ & $0.53 \pm 0.03 \mathrm{~b}$ & $0.53 \pm 0.02 \mathrm{~b}$ & Rootstock mean \\
\hline 2015 & $\begin{array}{l}\text { Colt } \\
\text { Damil } \\
\text { Gisela 5 } \\
\text { P-HL A } \\
\text { Tabel-Edabriz } \\
\text { Weiroot } 10\end{array}$ & $\begin{array}{c}0.75 \pm 0.04 \mathrm{aB} \\
0.79 \pm 0.02 \mathrm{aB} \\
0.87 \pm 0.02 \mathrm{bC} \\
0.91 \pm 0.03 \mathrm{cC} \\
0.68 \pm 0.03 \mathrm{cA} \\
0.63 \pm 0.02 \mathrm{bA}\end{array}$ & $\begin{array}{l}0.72 \pm 0.02 \mathrm{aB} \\
0.75 \pm 0.02 \mathrm{aB} \\
0.72 \pm 0.03 \mathrm{aB} \\
0.72 \pm 0.02 \mathrm{aB} \\
0.51 \pm 0.02 \mathrm{aA} \\
0.49 \pm 0.01 \mathrm{aA}\end{array}$ & $\begin{array}{l}0.74 \pm 0,01 \mathrm{aBC} \\
0.75 \pm 0.04 \mathrm{aBC} \\
0.72 \pm 0.01 \mathrm{aB} \\
0.78 \pm 0.06 \mathrm{abC} \\
0.56 \pm 0.02 \mathrm{abA} \\
0.51 \pm 0.01 \mathrm{aA}\end{array}$ & $\begin{array}{l}0.72 \pm 0,01 \mathrm{aC} \\
0.81 \pm 0.06 \mathrm{aD} \\
0.72 \pm 0.02 \mathrm{aC} \\
0.81 \pm 0,01 \mathrm{bD} \\
0.61 \pm 0.01 \mathrm{bB} \\
0.51 \pm 0.01 \mathrm{aA}\end{array}$ & $\begin{array}{l}0.73 \pm 0.01 \mathrm{c} \\
0.78 \pm 0.03 \mathrm{de} \\
0.76 \pm 0.06 \mathrm{~d} \\
0.80 \pm 0.07 \mathrm{e} \\
0.59 \pm 0.06 \mathrm{~b} \\
0.53 \pm 0.06 \mathrm{a}\end{array}$ \\
\hline Harvest/Storage means & & $0.77 \pm 0.10 \mathrm{c}$ & $0.65 \pm 0.17 \mathrm{a}$ & $0.68 \pm 0.15 \mathrm{~b}$ & $0.70 \pm 0.16 b$ & \\
\hline
\end{tabular}

*Means followed by the same small letter within a row and capital letter within a column, for each year, do not differ significantly at $\alpha=0.05$

Table 4 Soluble solids to acids ratio (SSC/TA) of 'Regina' sweet cherry directly after harvest and storage as affected by rootstock and storage conditions

\begin{tabular}{|c|c|c|c|c|c|c|}
\hline \multirow[t]{2}{*}{ Year } & \multirow{2}{*}{$\begin{array}{l}\text { Rootstock } \\
\text { (A) }\end{array}$} & \multirow[t]{2}{*}{ Harvest } & \multicolumn{3}{|c|}{ Storage conditions (B) } & \multirow[t]{2}{*}{ Rootstock means } \\
\hline & & & NA & CA 1 & CA 2 & \\
\hline 2014 & $\begin{array}{l}\text { Colt } \\
\text { Damil } \\
\text { Gisela } 5 \\
\text { Mazzard F } 12.1 \\
\text { P-HL A } \\
\text { Tabel-Edabriz } \\
\text { Weiroot } 10\end{array}$ & $\begin{array}{l}24.9 \pm 0.73 \mathrm{aC} * \\
25.7 \pm 0.24 \mathrm{aC} \\
25.4 \pm 0.93 \mathrm{aC} \\
17.0 \pm 0.82 \mathrm{aA} \\
21.7 \pm 0.65 \mathrm{aB} \\
26.7 \pm 0.24 \mathrm{aC} \\
21.4 \pm 0.57 \mathrm{aB}\end{array}$ & $\begin{array}{l}31.2 \pm 1.33 \mathrm{bBC} \\
33.9 \pm 1.29 \mathrm{bC} \\
34.0 \pm 1.41 \mathrm{cC} \\
23.1 \pm 1.34 \mathrm{bA} \\
30.0 \pm 2.68 \mathrm{bB} \\
39.0 \pm 1.89 \mathrm{cD} \\
30.5 \pm 1.51 \mathrm{cB}\end{array}$ & $\begin{array}{l}29.0 \pm 0.78 \mathrm{bBCD} \\
30.7 \pm 0.81 \mathrm{bCD} \\
31.9 \pm 0.95 \mathrm{bcD} \\
20.6 \pm 1.08 \mathrm{bA} \\
27.6 \pm 1.23 \mathrm{bB} \\
35.0 \pm 0.46 \mathrm{bE} \\
28.4 \pm 1.27 \mathrm{bcBC}\end{array}$ & $\begin{array}{l}28.8 \pm 0.64 \mathrm{bBC} \\
31.3 \pm 0.42 \mathrm{bCD} \\
31.0 \pm 1.21 \mathrm{bCD} \\
20.9 \pm 0.61 \mathrm{bA} \\
27.5 \pm 0.66 \mathrm{bB} \\
33.0 \pm 1.16 \mathrm{bD} \\
26.9 \pm 0.56 \mathrm{bB}\end{array}$ & $\begin{array}{l}28.5 \pm 2.27 \mathrm{c} \\
30.4 \pm 2.97 \mathrm{~d} \\
30.6 \pm 3.18 \mathrm{~d} \\
20.4 \pm 2.19 \mathrm{a} \\
26.7 \pm 3.06 \mathrm{~b} \\
33.4 \pm 4.44 \mathrm{e} \\
26.8 \pm 3.37 \mathrm{~b}\end{array}$ \\
\hline Harvest/Storage means & & $23.3 \pm 3,17 \mathrm{a}$ & $31.6 \pm 4.80 \mathrm{c}$ & $29.0 \pm 4.26 \mathrm{~b}$ & $28.5 \pm 3.80 \mathrm{~b}$ & Rootstock mean \\
\hline 2015 & $\begin{array}{l}\text { Colt } \\
\text { Damil } \\
\text { Gisela 5 } \\
\text { P-HL A } \\
\text { Tabel-Edabriz } \\
\text { Weiroot } 10\end{array}$ & $\begin{array}{l}22.0 \pm 0.22 \mathrm{aC} \\
23.7 \pm 0.65 \mathrm{aCD} \\
19.7 \pm 0.49 \mathrm{aB} \\
17.3 \pm 0.63 \mathrm{aA} \\
32.9 \pm 0.69 \mathrm{aE} \\
25.6 \pm 0.82 \mathrm{aD}\end{array}$ & $\begin{array}{l}24.3 \pm 0.40 \mathrm{bA} \\
24.5 \pm 0.31 \mathrm{aA} \\
23.1 \pm 1.28 \mathrm{bA} \\
22.6 \pm 0.86 \mathrm{cA} \\
43.1 \pm 1.73 \mathrm{cC} \\
32.4 \pm 0.39 \mathrm{bB}\end{array}$ & $\begin{array}{l}23.8 \pm 0.29 \mathrm{abB} \\
23.9 \pm 1.65 \mathrm{aB} \\
23.4 \pm 0.48 \mathrm{bB} \\
20.3 \pm 1.37 \mathrm{bA} \\
39.3 \pm 1.34 \mathrm{bD} \\
31.7 \pm 1.84 \mathrm{bC}\end{array}$ & $\begin{array}{l}23.7 \pm 0.50 \mathrm{abB} \\
22.7 \pm 1.72 \mathrm{aB} \\
22.9 \pm 0.17 \mathrm{bB} \\
19.0 \pm 0.25 \mathrm{abA} \\
37.5 \pm 0.85 \mathrm{bD} \\
31.4 \pm 0.57 \mathrm{bC}\end{array}$ & $\begin{array}{l}23.4 \pm 0.87 \mathrm{bc} \\
23.7 \pm 0.65 \mathrm{c} \\
22.3 \pm 1.50 \mathrm{~b} \\
19.8 \pm 1.94 \mathrm{a} \\
38.5 \pm 4.08 \mathrm{e} \\
30.3 \pm 2.72 \mathrm{~d}\end{array}$ \\
\hline Harvest/Storage means & & $23.5 \pm 4,97 \mathrm{a}$ & $28.5 \pm 8.97 \mathrm{c}$ & $27.1 \pm 7.31 \mathrm{~b}$ & $26.2 \pm 7.30 \mathrm{~b}$ & \\
\hline
\end{tabular}

*Means followed by the same small letter within a row and capital letter within a column, for each year, do not differ significantly at $\alpha=0.05$ 
of rootstocks on the value of this parameter was diversified, whereby the fruits from the Tabel-Edabriz $(16.7 \%$ and $22.5 \%$, first and second year, respectively) and Damil (16.3\% and $18.3 \%$, respectively) rootstocks were characterized by high mean SSC. At harvest time and after the storage period in all storage conditions, the fruits from the Mazzard F12.1 rootstock in the first year and P-HL A rootstock in the second year were characterized by lower SSC values than other rootstocks. On the other hand, the fruits from the NA and CA1 conditions exhibited higher SSC in relation to harvest time on the Tabel-Edabriz and Weiroot 10 rootstocks in the first year, and on the Colt rootstock in the second year.

\subsubsection{Titratable acidity (TA)}

During the experimental years, a significant effect was found between the studied factors and TA in fruits. In both years, the organic acids content was significantly lower after storage compared to at harvest time (Table 3). Also, in both years, the CA1 and CA 2 conditions inhibited the disintegration of organic acids in stored fruits much more effectively than the NA condition. In the two years, fruits from the P-HL A rootstock were characterized by high organic acid content. Fruits from the Tabel-Edabriz rootstock (both years) and the Weiroot 10 rootstock (second year) exhibited the highest decrease in titratable acids content. Organic acids content measured at harvest time was generally significantly higher than after fruit storage, except for fruits from the Colt and Damil rootstocks in the second year.

\subsubsection{SSC to TA ratio}

The studied factors had a significant impact on the SSC/ TA ratio in fruits over both experimental years. The SSC/ TA ratio was higher after the storage period than at harvest time (Table 4). The SSC/TA ratio was highest in fruit stored under the NA condition. The composition of the controlled atmospheres (CA1 and CA2) did not affect the value of the discussed ratio. Rootstock type had a significant effect on the SSC/TA ratio in both years, and the ratio was highest on the Tabel-Edabriz rootstock (33.4 and 38.5, first and second year, respectively). A low SSC/TA ratio was found in fruits from the Mazzard F12.1 and P-HL A rootstocks in the first year and the P-HL A rootstock in the second year. Generally, this ratio was higher after storing than at harvest time, except for the Damil rootstock in the second year.

\subsubsection{Natural weight losses}

Fruit mass loss is one of the adverse effects of fruit storage (Fig. 1).

The value of this parameter was affected only by the storage conditions, whereas fruit weight was significantly higher after storage in the NA condition than in other two storage conditions. The composition of the controlled atmospheres did not affect fruit weight losses in either years.

\subsubsection{Fungal decay}

After storing, fungal decay caused by Monilinia laxa was observed (Table 5). Generally, the sweet cherry fruits were healthy after the storage period. Fungal decay in fruit depended on both storage conditions and rootstock type, and the interaction between the studied factors. The highest percentage of fruit with symptoms of fungal diseases was recorded in NA. In the first year, the most decayed fruits were found from the Mazzard F12.1 rootstock (4.1\%). The degree of fruit infection from the Damil, Gisela 5, TabelEdabriz and Weiroot 10 rootstocks was low, less than $1 \%$ each. In the second year, fruits from the Weiroot 10 rootstock exhibited greater susceptibility to fungal diseases. Interactions between studied factors were also found, but the effect of these interaction depended on the year.

\subsubsection{Maintenance of green peduncle}

Sweet cherry fruits are harvested and stored together with the peduncle. After the storage period, their quality was assessed in terms of how well the green color was preserved in the peduncle. The influence of refrigeration conditions became apparent in the second year of research, while the type of rootstock had a significant impact on this trait in both years of the experiment (Fig. 2 and 3).

The high concentration of $\mathrm{CO}_{2}$ under the cold conditions of CA1 and CA2 contributed to the preservation of the green color in the peduncle in up to $80 \%$ of the fruits. In regard to rootstocks, Colt, Gisela 5 and P-HL A in particular positively affected the preservation of peduncle color.

\section{Discussion}

Weather conditions during fruit ripening and fruit growth directly after harvesting have huge impacts on the quality characteristics of harvested fruits, as well as their quality after storage. In the present experiment, rootstock did not appear to affect fruit firmness, unlike in our previous research (Dziedzic et al. 2016, 2017). Over the two years of study, the weather parameters were measured until fruit harvesting, and weather conditions were found to be different between the two years. In second year, the mean temperature was slightly higher $\left(1.6^{\circ} \mathrm{C}\right)$, wherein the mean sum of precipitation was lower $(11.1 \mathrm{~mm})$ compared to the first year; hence, the second year was recognized as warmer and dryer. The discussed studies proved that after harvest the fruit exhibited better quality parameters-i.e., firmness 


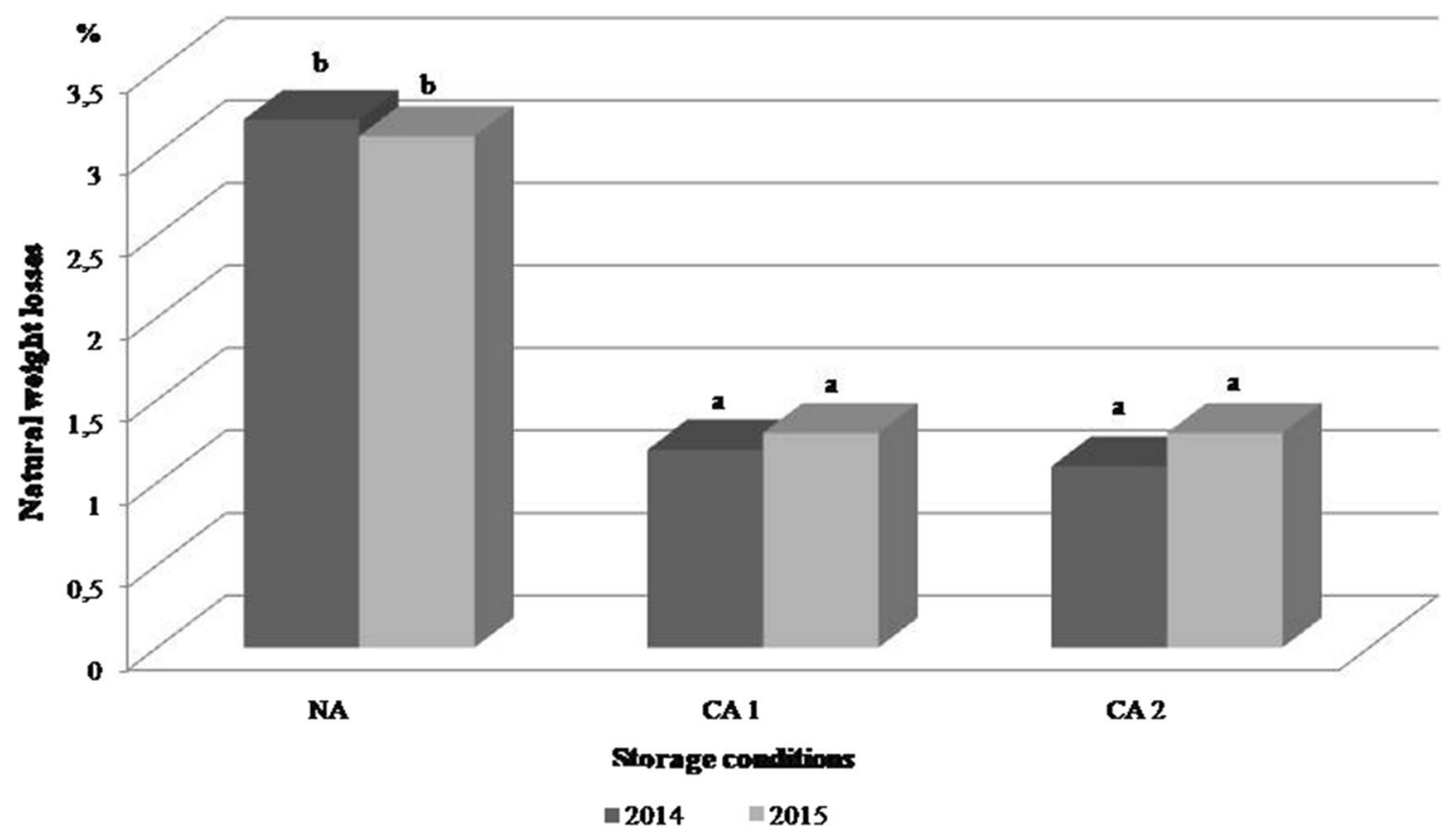

Fig. 1 Natural weight loss (\%) of 'Regina' sweet cherry directly after storage as affected by storage conditions

Table 5 Percent of 'Regina' sweet cherry with brown rot symptoms directly after storage as affected by rootstock and storage conditions

\begin{tabular}{llllll}
\hline Year & $\begin{array}{l}\text { Rootstock } \\
\text { (A) }\end{array}$ & \multicolumn{2}{l}{ Storage conditions (B) } & \multirow{2}{*}{ Rootstock means } \\
\cline { 2 - 4 } & NA & CA 1 & CA 2 & \\
\hline 2014 & Colt & $4.4 \mathrm{cC} *$ & $0.0 \mathrm{aA}$ & $1.8 \mathrm{bB}$ & $2.1 \mathrm{c}$ \\
& Damil & $1.0 \mathrm{bAB}$ & $0.0 \mathrm{aA}$ & $0.0 \mathrm{aA}$ & $0.3 \mathrm{a}$ \\
& Gisela 5 & $1.1 \mathrm{bAB}$ & $0.5 \mathrm{bA}$ & $0.0 \mathrm{aA}$ & $0.5 \mathrm{ab}$ \\
& Mazzard F 12.1 & $5.4 \mathrm{bC}$ & $4.3 \mathrm{bC}$ & $2.5 \mathrm{aB}$ & $4.1 \mathrm{~d}$ \\
& P-HL A & $1.9 \mathrm{bB}$ & $2.4 \mathrm{bB}$ & $0.0 \mathrm{aA}$ & $1.4 \mathrm{bc}$ \\
& Tabel-Edabriz & $1.7 \mathrm{cAB}$ & $0.0 \mathrm{aA}$ & $0.5 \mathrm{bA}$ & $0.7 \mathrm{ab}$ \\
Storage means & $0.5 \mathrm{aA}$ & $0.5 \mathrm{aA}$ & $1.7 \mathrm{bB}$ & $0.9 \mathrm{ab}$ \\
2015 & Weiroot 10 & $2.3 \mathrm{~b}$ & $1.0 \mathrm{a}$ & $1.0 \mathrm{a}$ & Rootstock means \\
& & $3.3 \mathrm{bAB}$ & $3.1 \mathrm{bB}$ & $0.5 \mathrm{aA}$ & $2.3 \mathrm{a}$ \\
& Colt & $2.8 \mathrm{bA}$ & $2.7 \mathrm{bB}$ & $0.0 \mathrm{aA}$ & $1.8 \mathrm{a}$ \\
& Damil & $4.5 \mathrm{cBC}$ & $2.6 \mathrm{bB}$ & $0.0 \mathrm{aA}$ & $2.4 \mathrm{a}$ \\
& Gisela 5 & $5.4 \mathrm{bCD}$ & $0.0 \mathrm{aA}$ & $0.3 \mathrm{aA}$ & $1.9 \mathrm{a}$ \\
& P-HL A & $6.7 \mathrm{bDE}$ & $0.0 \mathrm{aA}$ & $0.0 \mathrm{aA}$ & $2.2 \mathrm{a}$ \\
Tabel-Edabriz & $7.5 \mathrm{cE}$ & $4.3 \mathrm{bC}$ & $0.0 \mathrm{aA}$ & $3.9 \mathrm{~b}$ \\
\hline
\end{tabular}

*Means followed by the same small letter within a row and capital letter within a column, for each year, do not differ significantly at $\alpha=0.05$ and SSC - in the second year. Rootstocks can have different effects on the cultivars of sweet cherries grafted on them under different climatic and soil conditions (Hilsendegen 2004; Wociór 2008; Cantin et al. 2010) and can modify a wide range of fruit quality parameters (Gonçalves et al. 2005; Lugli and Sansavini 2008; Rozpara 2008; Kankaya et al. 2008). Our previous research (Dziedzic 2012; Dziedzic et al. 2016, 2017), as well as the current study, indicate that vigorous rootstocks, especially the Mazzard F12.1 clone, significantly affect the level of SSC in cherry fruits.
The SSC to TA ratio is often referred to as the 'ripening index', and it can be used to very precisely determine the optimal date for harvesting sweet cherries, as demonstrated by Çalhan et al. (2014). Index is also an indicator of the readiness of dessert fruits for consumption and has a great importance for measuring the taste perceived by consumers. In our previous studies (Dziedzic 2012; Dziedzic et al. 2016, 2017), the index was generally high, which was related to the relatively low content of organic acids. The highest rated fruits by consumers were also characterized by high values 


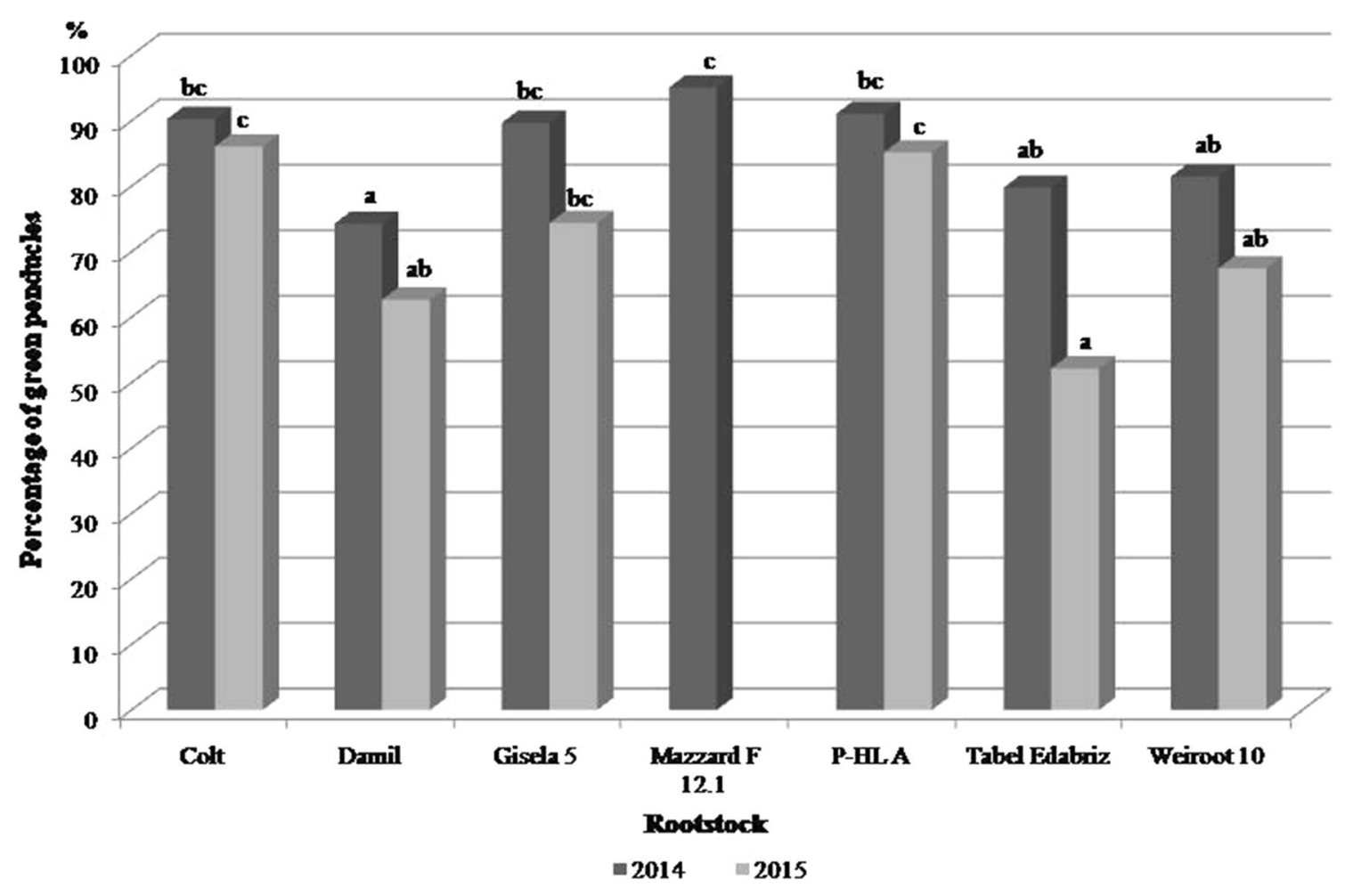

Fig. 2 Percentage of green peduncles in 'Regina' sweet cherry directly after storage as affected by rootstock

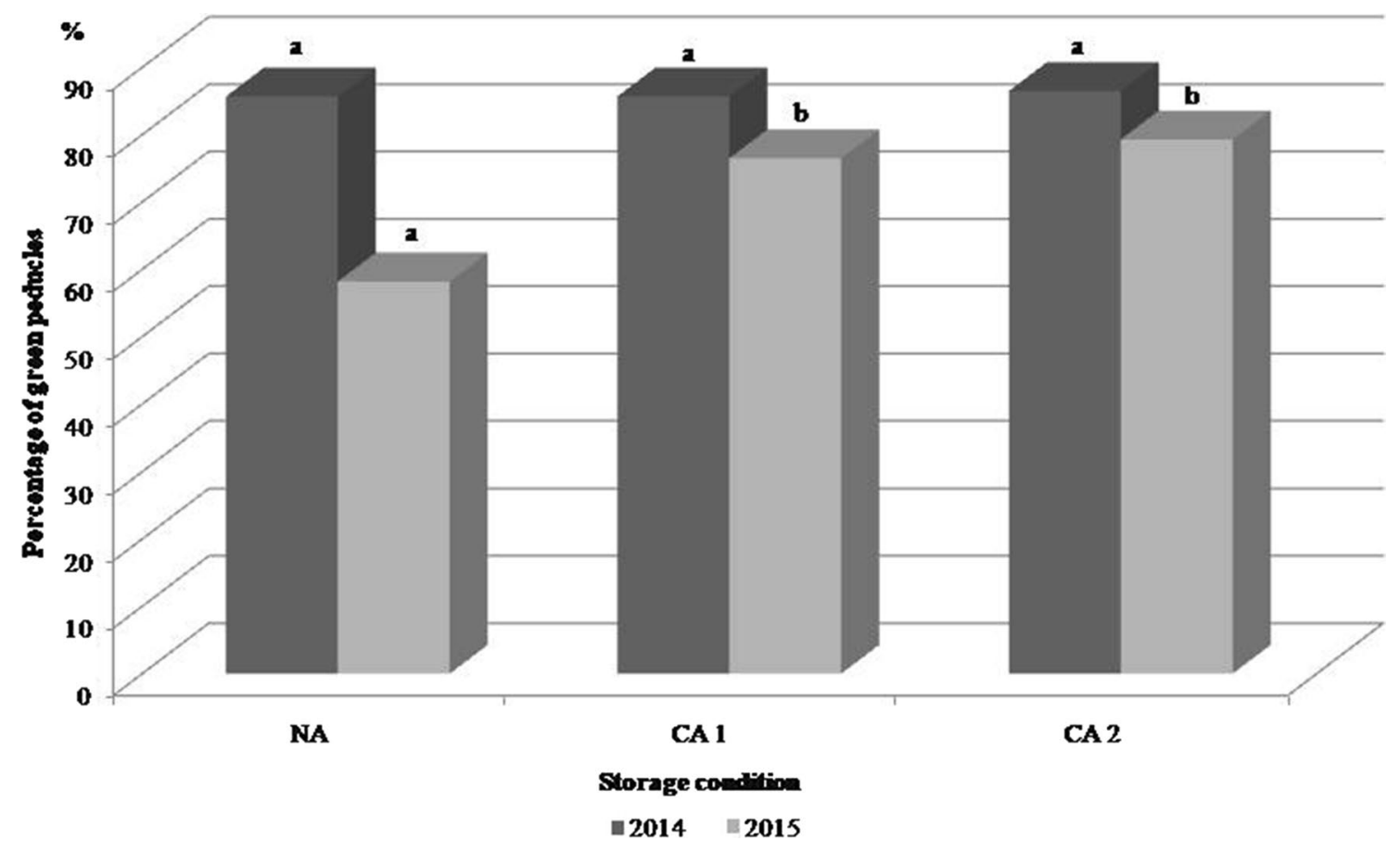

Fig. 3 Percentage of green peduncles in 'Regina' sweet cherry directly after storage as affected by storage conditions 
of this coefficient (over 30) (Crisosto et al. 2003; Turner et al. 2008).

Sweet cherries can generally be stored for 1-4 weeks at $0{ }^{\circ} \mathrm{C}$ and $90 \%$ relative humidity (RH) (Esti et al. 2002). After fruit storage, we did not observe any injury from $\mathrm{CO}_{2}$. According to the literature, the sweet cherry fruits are more resistant to high concentrations of $\mathrm{CO}_{2}$, even $20 \%$, than pome fruits are (Jiang et al. 2002; Goliaš et al. 2006). Maintaining satisfactory firmness of the flesh after fruit storage in a cold room is one of the most important goals, because sweet cherries belong to a group of perishable fruits harvested at the stage of consumption maturity. We noted that the use of high $\mathrm{CO}_{2}$ concentrations $(15 \%$ and $20 \%$ in CA1 and CA2, respectively) in the controlled atmosphere chambers influenced the preservation of firmness in comparison to the measurement directly after fruit harvest. In the present experiment, we found that only the storage conditions affected fruit firmness, while the effect of the rootstocks (on which the cherry trees were grown) was negligible, similar to our earlier studies (Dziedzic et al. 2016, 2017) and in contrast to Cavalhiero et al. (2005).

Our observations, indicating that high $\mathrm{CO}_{2}$ concentration and low temperature favor preserving high fruit firmness, are consistent with the results in other experiments-e.g., for the cultivars 'Napoleon' (Jiang et al. 2002) and 'Vanda' and 'Van' (Goliáš et al. 2006). According to the latest observations, biochemical processes (associated with cell wall modification), resulting from enzymatic activity and dehydroascorbic acid content, are responsible for maintaining or decreasing fruit firmness after storage (Belge et al. 2015). Individual sweet cherry cultivars vary in the contents of these components, hence their different susceptibility to storage conditions.

There are several reasons for the changes in SSC content in fruits during storage. These changes are the result of metabolic changes during fruit ripening, sugar concentrations under low temperature, and dehydration of fruit tissue (Kappel et al. 2002; Cavalheiro et al. 2005; Horák et al. 2016). Wang and Vestrheim (2002) and Tian et al. (2004) reported that increasing the $\mathrm{CO}_{2}$ content in the atmosphere during sweet cherry storage helped maintain high fruit quality. First of all, attention should be paid to preserve a high level of fruit SSC after storage, because it affects the taste assessment. Only the Damil, Gisela 5 and Tabel Edabriz rootstocks affected the fruit SSC level that is widely accepted by consumers, i.e., $\geq 16 \%$ in both years of the experiment, in all tested storage combinations (Kappel et al. 1996). The study of Cavalheiro et al. (2005) confirmed the Tabel Edabriz rootstock contributed to the high SSC content in fruits after 42 days of storage.

Changes related to organic acid content occur in parallel to SSC changes in fruits, because organic acids, like sugars, are the basic substrates in the process of fruit respiration
(Wang and Lang 2014; Wani et al. 2014). Studies indicate that sweet cherries are characterized by high respiration intensity, which adversely affects internal and external changes in fruit quality (Akbudak et al. 2008, 2009). The beneficial effect of high $\mathrm{CO}_{2}$ concentration in reducing the decrease in organic acid contents demonstrated in the present experiment is consistent with other studies (Esti et al. 2002; Tian et al. 2004). Acids content is associated with $\mathrm{pH}$ values, and as $\mathrm{pH}$ increases, the color of anthocyanins changes (Gonçalves et al. 2007). We emphasize that changes in fruit TA content after storage are strongly influenced by rapid cooling (with air or water) of fruits directly after harvest, preferably up to $4 \mathrm{~h}$ (Bernalte et al. 2003; Akbulut et al. 2008). Our evaluation of the impact of several rootstocks on the TA level after fruit storage is a novelty of our research. In our experiment, low TA values were recorded for fruits from the Tabel Edabriz rootstock, just like in Cavalheiro et al. (2005) under the same CA conditions, i.e., $15 \%$ and $20 \% \mathrm{CO}_{2}$ concentrations.

As already mentioned above, the ratio of SSC to TA is a very important parameter of fruit quality assessment. The high value of this coefficient in the present study in fruits after storage is in accordance with our expectations and confirmed by our previous observations (Dziedzic et al. 2016, 2017). According to Crisosto et al. (2003) and Kalyoncu et al. (2009), the higher this coefficient, the better consumers judge a fruit to be. The index has an impact on consumer taste impressions; for sweet cherries, which are mainly dessert fruits, it should be higher than 20 (Kader 1999). The level of this coefficient is influenced by all changes in SSC content and TA, and these variables are known to depend on the impact of storage conditions and rootstocks.

The observed decreases in fruit weight after storage are mainly due to the loss of water through the fruit and peduncle, resulting in fruit skin wrinkling and wilting, and even drying of the peduncle, with the peduncle showing eight times higher water losses compared to the fruit (Linke et al. 2010). Sweet cherry fruits are characterized by low resistance to diffusion through the skin and a higher surface area vs. volume than other fruits (Wani et al. 2014). Our study recorded weight losses only in relation to the storage conditions (three times higher in NA than in both CA combinations), and many other authors have observed the same trend in other sweet cherry cultivars (Szymczak et al. 2003; Padilla-Zakour et al. 2004; Goliáš et al. 2007). Loss of fruit mass during storage affects the shelf-life and deteriorates fruit quality after storage (Serrano et al. 2005).

High sensitivity to fungal diseases in sweet cherry fruits is one of the factors preventing them from being stored longer. In temperate climate conditions during the cherry harvest period, precipitation often occurs and reduces the value of fruit with delicate flesh and thin skin. In our research, such a relationship was observed in 2015 , when there was an 
increased rainfall before the fruit harvest. After storage, the percentage of fruits showing fungal decay was greater in this year, especially in the NA condition. A higher percentage of fruit fungal diseases from individual rootstocks was also observed that year.

Only cold storage with higher $\mathrm{CO}_{2}$ concentration (20\%) effectively reduced fungal fruit infections. The presented results are consistent with our previous observations (Dziedzic et al. 2017), where we showed that atmosphere composition (increased $\mathrm{CO}_{2}$ concentration) had a more favorable effect on reducing diseases compared to low temperature; they are also in line with the results obtained by Tian et al. (2004). DeVries-Patterson et al. (1991) showed that high $\mathrm{CO}_{2}$ concentration reduced the risk of fungal fruit infection during storage, and sweet cherries tolerate such atmospheric gas composition particularly well (Wang and Vestrheim 2002).

Increasingly, attention is also being paid to the appearance of the fruit peduncle, which is an important element affecting the assessment of fruit quality. Sweet cherries, as typical dessert fruits, are collected and stored together with peduncles, which prevents juice leaking from the flesh of the fruits. Currently, consumers prefer new sweet cherry cultivars with a short peduncle (Gjamovski et al. 2016) over the local cultivars characterized by a long peduncle, and this significantly hampers the harvest (Perez-Sanchez et al. 2010). However, the presence of oxygen in the air and high temperature cause that the peduncle to quickly release water and the chlorophyll in its tissues to degrade after the harvest (Sen et al. 2014); therefore, the preservation of green color in the peduncle is one of the determinants for assessing good fruit quality after storage. Atmosphere composition (Drake and Elfving 2002) as well as humidity and temperature (Goliaš et al. 2006, 2007) are factors that play a major role in maintaining the green peduncle. The present results in the second year indicate that the controlled atmosphere has a beneficial effect on a high percentage of fruits with a green peduncle. In our previous studies (Dziedzic et al. 2016, 2017), we also noted a high percentage of green in peduncles under $\mathrm{CA}$ conditions, despite the lower $\mathrm{CO}_{2}$ content compared to the current experiment. Different rootstocks were also observed to have different effects on the greenness of the peduncle; in particular, the Gisela 5 and P-HL A and Colt rootstocks showed a satisfactory effect on this trait, as in other studies (Cavalheiro et al. 2005; Dziedzic et al. 2016, 2017).

\section{Conclusions}

The weather conditions prevailing in a given year have a significant impact on fruit quality during harvest and after storage. Cold storage in a controlled atmosphere with a high $\mathrm{CO}_{2}$ content is recommended for the short-term storage of sweet cherry fruits because it preserved several fruit quality parameters: the maintenance of fruit firmness and titratable acidity at a good level, high SSC to TA ratio, low fruit weight losses, low percent of fungal infections caused by Monilinia laxa, good preservation of green color in the peduncle. The rootstocks on which the trees grew affected not only fruit quality parameters during harvest, but also their preservation after the storage period, except the fruit firmness.

Acknowledgements This work was supported by The Ministry of Science and Higher Education in Poland (project number DS-3500).

Author contribution ED and JB performed the experiments, analyzed the data and wrote the paper.

\section{Compliance with ethical standards}

Conflict of interest The authors declare that they have no conflict of interest.

Open Access This article is distributed under the terms of the Creative Commons Attribution 4.0 International License (http://creativeco mmons.org/licenses/by/4.0/), which permits unrestricted use, distribution, and reproduction in any medium, provided you give appropriate credit to the original author(s) and the source, provide a link to the Creative Commons license, and indicate if changes were made.

\section{References}

Akbudak B, Tezcan H, Eris A (2008) Determination of controlled atmosphere storage conditions for 0900 Ziraat sweet cherry fruit. Acta Hortic 795:855-859

Akbudak B, Tezcan H, Eris A (2009) Evaluation of messenger plant activator as a preharvest and postharvest treatment of sweet cherry fruit under a controlled atmosphere. Int J Food Sci Nutr 60:374-386

Akbulut M, Özcan M (2008) Effects of various precooling applications on postharvest quality of 0900 Ziraat sweet cherries. Acta Hortic 795:811-814

Balmer M (2008) Evaluation of semi-dwarfing rootstocks for sweet cherry orchards in the Rhine river valley (Germany). Acta Hortic 795:203-207

Belge B, Comabella E, Graell J, Lara I (2015) Post-storage cell wall metabolism in two sweet cherry (Prunus avium L.) cultivars displaying different postharvest performance. Food Sci Technol Int 21:416-427

Bernalte MJ, Sabio E, Hernández MT, Gervasini C (2003) Influence of storage delay on quality of 'Van' sweet cherry. Postharvest Biol Technol 28:303-312

Bielicki P, Rozpara E (2010) Growth and yielding of Kordia sweet cherry trees with various rootstock and interstem combinations. J Fruit Ornam Plant Res 18(1):45-50

Brüggenwirth M, Knoche M (2016) Mechanical properties of skins of sweet cherry fruit of differing susceptibilities to cracking. J Am Soc Hortic Sci 141:162-168

Çalhan O, Onursal CE, Guneyli A, Eren İ, Demirtaş İ (2014) Determination of optimum harvest date of sweet cherry cv. Lapins grown in Isparta. Turk J Agric Nat Sci 2:1905-1910

Candan AP, Graell J, Larrigaudiere C (2011) Postharvest quality and chilling injury of plums: benefits of 1-methylcyclopropene. Span J Agric Res 9(2):554-564 
Cantin CM, Pinochet J, Gogorcena Y, Moreno MA (2010) Growth, yield and fruit quality of 'Van' and 'Stark Hardy Giant' sweet cherry cultivars as influenced by grafting on different rootstocks. Sci Hortic 123:329-335

Cavalheiro JT, Santos AA, Marques RI, Pirra A, Silvestre A (2005) Rootstock and storage regime influence 'Summit' cherry quality. Acta Hortic 682:1179-1183

Crisosto CH, Crisosto GM, Metheney P (2003) Consumer acceptance of 'Brooks' and 'Bing' cherries is mainly dependent on fruit SSC and visual skin color. Postharvest Biol Technol 28:159-165

DeVries-Patterson RM, Jones AL, Cameron AC (1991) Fungistatic effects of carbon dioxide in a package environment on the decay of Michigan sweet cherries by Monilinia fructigena. Plant Dis 75:943-946

Drake SR, Elfving DC (2002) Indicators of maturity and storage quality of 'Lapins' sweet cherry. HortTechnology 12(4):687-690

Dziedzic E (2012) Zastosowanie kultur in vitro w produkcji materiału szkółkarskiego. Zesz Nauk UR w Krakowie, 362, p 102 (in Polish, summary in English)

Dziedzic E, Błaszczyk J, Kaczmarczyk E (2016) Influence of rootstocks and storage conditions on the quality of sweet cherry fruits 'Regina'. Acta Sci Pol Hortorum Cultus 15:119-131

Dziedzic E, Błaszczyk J, Kaczmarczyk E (2017) Postharvest properties of sweet cherry fruit depending on rootstock and storage conditions. Folia Hortic 29:113-121

Esti M, Cinquanta L, Silesio F, Moneta E, Di Matteo M (2002) Physicochemical and sensory fruit characteristics of two sweet cherry cultivars after cool storage. Food Chem 76:399-405

Gjamovski V, Kiprijanovski M, Arsov T (2016) Evaluation of some cherry varieties grafted on Gisela 5 rootstock. Turk J Agric For 40:737-745

Goliáš J, Lacný Z, Němcová A, Čaněk A (2006) Release of anaerobic metabolites from intact sweet cherries in low oxygen atmospheres. Mitt Klosternn 56:157-165

Goliáš J, Němcová A, Čaněk A, Kolenčíková D (2007) Storage of sweet cherries in low oxygen and high carbon dioxide atmospheres. Hortic Sci (Prague) 34:26-34

Gonçalves B, Moutinho-Pereira J, Santos A, Silva AP, Bacelar E, Correia C, Rosa E (2005) Scion-rootstock interaction affects the physiology and fruit quality of sweet cherry. Tree Physiol 26:93-104

Gonçalves B, Silva AP, Moutinho-Pereira J, Bacelar E, Rosa E, Meyer AS (2007) Effect of ripeness and postharvest storage on the evolution of color and anthocyanins in cherries (Prunus avium L.). Food Chem 103:976-984

Gratacós E, Cortés A, Kulczewski BM (2008) Flowering, production and fruit quality of eleven sweet cherry cultivars in central Chile. Acta Hortic 795:331-338

Hilsendegen P (2004) Preliminary results of a German sweet cherry rootstock trial. Acta Hortic 658:151-157

Horák M, Goliáš J, Híc P, Němcová A, Kulichová J (2016) The effect of post-harvest treatment on the quality of sweet cherries during storage. Potravinarstvo 10:570-577

Jiang AL, Tian SP, Xu Y (2002) Effect of controlled atmospheres with high-O2 and high $\mathrm{CO} 2$ concentrations on postharvest physiology and storability of 'Napoleon' sweet cherry. Acta Bot Sin 44:925-930

Kader AA (1999) Fruit maturity, ripening and quality relationships. Acta Hortic 485:203-208

Kalyoncu IH, Ersoy N, Yilmaz M (2009) Some physico-chemical properties and mineral contents of sweet cherry (Prunus avium L.) type grown in Konya. Afr J Biotechnol 8:2744-2749

Kankaya A, Askin MA, Akinci-Yildrim F, Balci B, Alkan T (2008) Evaluation of some sweet cherry cultivars on Gisela 5 and Gisela 6 rootstocks in Baryamic, Turkey. Acta Hortic 795:221-225
Kappel F, Fisher-Fleming B, Hogue E (1996) Fruit characteristics and sensory attributes of an ideal sweet cherry. HortScience 31:443-446

Kappel F, Toivonen P, McKenzie DL, Stan S (2002) Storage characteristics of new sweet cherry cultivars. HortScience 37:139-143

Karlidag H, Ercisli S, Sengul M, Tosun M (2009) Physico-chemical diversity in fruits of wild growing sweet cherries (Prunus avium L.). Biotechnol BiotecEq 23(3):1325-1329

Khorshidi S, Davarynejad G, Tehranifar A, Fallahi E (2011) Effect of modified atmosphere packaging on chemical composition, antioxidant activity, anthocyanin, and total phenolic content of cherry fruits. Hortic Environ Biotechnol 52:471-481

Koutinas N, Pepelyankov G, Lichev V (2010) Flower induction and flower bud development in apple and sweet cherry. Biotechnol Biotec Eq 24:1549-1558

Kurlus R (2008) Rootstock effects on growth, yield and fruit quality of two sweet cherry cultivars in Western Poland. Acta Hortic 795:293-297

Linke M, Herppich W, Geyer M (2010) Green peduncles may indicate postharvest freshness of sweet cherries. Postharvest Biol Technol $58: 135-141$

Lugli S, Sansavini S (2008) Preliminary results of a cherry rootstock trial in Vignola, Italy. Acta Hortic 795:321-326

Padilla-Zakour OI, Tandon KS, Wargo J (2004) Quality of modified atmosphere packaging 'Hedelfinden' and 'Lapins' sweet cherry. HortTechnology 14:331-337

Perez-Sanchez R, Gomez-Sanchez MA, Morales-Corts MR (2010) Description and quality evaluation of sweet cherries cultured in Spain. J Food Qual 33:490-506

Rozpara E (2008) Growth and yield of eleven sweet cherry cultivars in central Poland. Acta Hortic 795:571-576

Sen F, Oksar RF, Golkarian M, Yaldiz S (2014) Quality changes of different sweet cherry cultivars at various stages of the supply chain. Not Bot Hortic Agrobot 42:501-506

Serrano M, Martínez-Romero D, Castillo S, Guillén F, Valero D (2005) The use of anti-fungal compounds improves the beneficial effect of MAP in sweet cherry storage. Innov Food Sci Emerg 6:115-123

Simon G, Hrotkó K, Magyar L (2004) Fruit quality of sweet cherry cultivars grafted on four different rootstocks. Acta Hortic 658:365-370

Spinardi AM, Visai C, Bertazza G (2005) Effect of rootstock on fruit quality of two sweet cherry cultivars. Acta Hortic 667:201-206

Szymczak JA, Rutkowski KP, Miszczak A, Rozpara E (2003) Sensory evaluation of 'Kordia' sweet cherry after storage. Pol J Food Nutr Sci 12:45-49

Tian SP, Jiang AL, Xu Y, Wang YS (2004) Responses of physiology and quality of sweet cherry fruit to different atmospheres in storage. Food Chem 87:43-49

Turner J, Seavert C, Colonna A, Long LE (2008) Consumer sensory evaluation of sweet cherry cultivars in Oregon, USA. Acta Hortic 795:781-786

Wang Y, Lang L (2014) Respiration and quality responses of sweet cherry to different atmospheres during cold storage and shipping. Postharvest Biol Tec 92:62-69

Wang L, Vestrheim S (2002) Controlled atmosphere storage of sweet cherries (Prunus avium L.). Acta Agric Scand Sect B Soil Plant Sci 52:136-142

Wani AA, Singh P, Gul K, Wani MH, Langowski HC (2014) Sweet cherry (Prunus avium): critical factors affecting the composition and shelf life. Food Packag Shelf Life 1:86-99

Wociór S (2008) The effect of rootstocks on the growth and yielding of Regina cherry trees. Folia Hortic 20:15-22

Publisher's Note Springer Nature remains neutral with regard to jurisdictional claims in published maps and institutional affiliations. 